\title{
Review
}

\section{Evaluation of the National Education Council's Decisions regarding the Education of Gifted and Talented Students}

\section{Millî Eğitim Şûra Kararlarında Üstün Zekâlı ve Yetenekli (Özel Yetenekli) Bireylerin Eğitimi Üzerine Bir Değerlendirme}

\author{
Necati Bilgiç \& Ayşegül Ataman²
}

\begin{abstract}
An evaluation of the history of countries' education in helps us better understand the present and develop better future policies. In this study, the decisions taken on the education of special talents in the congresses of the National Education in Turkey held since the establishment of the Republic were critically evaluated. Document analysis, one of the qualitative research methods, was used. In this context, a total of nineteen councils were examined. As a result of the study, it was found that that there were studies for children in need of special education in the multiparty period and it was seen that detailed decisions regarding the education of talented individuals came forward after 2000s as a result of the developments in the world and the reflection of these developments to Turkey and the importance of the issue. Looking at the implementation of the recommendations of the decisions, it was seen that some decisions were applied, some decisions do not continue. Finally, when we look at the agenda items for the education of talented individuals in past councils, it was seen that it is not sustainable, it is more person-focused than system-oriented, and it is shaped according to government policies
\end{abstract}

Key Words: education of special talented individuals, educational policies, national education councils

\section{Öz}

Ülkelerin eğitime dair tarihsel sürecini değerlendirmek, bugünü daha iyi anlamamıza ve ileriye dönük politika belirlememize yardımcı olmaktadır. Bu çalışmada, Cumhuriyetin kuruluşundan günümüze kadar düzenlenen millî eğitim şûralarında özel yeteneklilerin eğitimine ilişkin alınan kararlar, tek partili dönemde düzenlenen şûralar, çok partili döneme geçiş sürecinde düzenlenen şûralar, çok partili dönemde düzenlenen şûralar, planlı dönemde düzenlenen şûralar, 1980 sonrası düzenlenen şûralar ve 2000 sonrası düzenlenen şûralar bağlamında değerlendirilmiştir. Nitel araştırma yöntemlerinden doküman incelemesi kullanılmıştır. Bu kapsamda günümüze kadar düzenlenen toplam on dokuz şûranın incelemesi yapılmıştır. Yapılan inceleme sonucunda çok partili dönemde özel eğitime gereksinimi olan çocuklara yönelik çalışmaların yer aldığı, özel yetenekli bireylerin eğitimine ilişkin ise ayrıntılı kararların dünyada meydana gelen gelişmeler ve söz konusu gelişmelerin ülkemize yansıması ile konunun önemsenmesi sonucu 2000'li yıllardan sonra öne çıktığı görülmektedir. Tavsiye niteliği taşıyan kararlarının uygulamalarına bakıldığında ise, bazı kararların uygulandığı bazı kararların ise devamının gelmediği görülmüştür. Son olarak; düzenlenen şûralarda yer alan özel yetenekli bireylerin eğitimine yönelik gündem maddelerine bakıldığında sürdürülebilir olmadığı, sistem odaklı olmaktan ziyade kişi odaklı olduğu ve hükümet politikalarına göre şekillendiği görülmektedir.

Anahtar Sözcükler: özel yetenekli bireylerin eğitimi, eğitim politikaları, millî eğitim şûraları

\section{Summary}

Purpose and Significance: The Councils are the most important supreme board and advisory body of the national ministry of education. Council decisions are not binding in terms of the relevant units of the Ministry of National Education but they are decisions that managers sometimes make to implement decisions that they consider important (Can, 1999). Decisions taken at the councils

\footnotetext{
${ }^{1}$ Correspondence Author, PhD, Ministry of Education, Ankara, Turkey; bilgicnecati@hotmail.com, ORCID: 0000-0002-7729-7442

2 Prof., Lefke European University Special Education Department, Cyprus, ORCID: 0000-0002-5566-6606

(C) Talent; ISSN 2717-7122 http://talentjournal.net
} 
and councils are advisory, it is important to establish a basis for the policies of the Ministry of National Education, and it is seen that thesis and articles about the institutions are made.

When we look at the studies on the education policies of the special talented individuals in our country, it is seen that there are generally various documents but there is no in-depth analysis of the existing documents and no studies have been found regarding the reflection of the decisions taken during the national education councils. When evaluated from this point of view, the decisions taken at the national education councils were evaluated and looked at their reflection on politics.

Methods: In this study, the decisions taken regarding the education of the special talented individuals during the 19 national education councils organized from the foundation of the Republic to the day-to-day were evaluated based on the classification made by Deniz (2001). In addition to the classification made by Deniz (2001), the sixth period was added by the authors to the year 2000 after the year 2000. For this purpose, document analysis, one of the qualitative research methods, was conducted in the research. It is important that one of the researchers has worked as an expert and manager in the field of education of special talents for many years and other researchers have also worked for many years in the same field, MEB and TUBITAK (Scientific and Technological Research Council of Turkey) is involved in the projects and scientific works in cooperation is also important

Results: Councils which are made from the Republican date to the present; it is seen that councils held in 1953, 1981, 1993 and 1996, which were reviewed and included in the opening speech of a council, in which a total of six council decisions were taken, were given recommendations under the name of children with special education needs. On the other hand, the council, which is held on various dates, made extensive decisions on the training of special talented individuals for the first time in 2006, XVII. It was taken in the National Education Council and it was held in XVIII. It is seen that National Education Council decisions are followed (Sak et al., 2015).

Conclusions: The arrangement of the councils and the determination of the issues can be said to be related to solving the problems of the period (Ambarl1, 2010). However, it can be said that the decisions taken by the councils are a recommendation and that some decisions cannot be implemented with some reason or that some decisions are abandoned after a short time.

\section{Giriş}

Özel yetenekli bireylerin eğitiminde tanım, tanılama, uygulamaya ilişkin modeller, bu çocukların özellikleri, toplum tarafından kabul görmeleri veya algılanmaları ve istihdamları uzun yıllar üzerinde çalışma yapılan temel konulardır. Yapılan tanımların kültürden kültüre değiştiği (Sak, 2010), tanılamaya ilişkin çalışmaların her zaman tartışıldığı ve tanılama yaklaşımının net olması gerektiği (Heller, 2004), uygulanacak eğitim modellerinin iyi belirlenmesi, kültüre ve sisteme uyum sağlaması gerektiği (Davaslıgil, 2004), özelliklerine ilişkin yapılan araştırmalar ve elde edilen bulgular ile istihdamlarına yönelik yapılan çalışmalar bugünde halen üzerinde tartışılan konular arasındadir. 
Ülkemizde özel yetenekli bireylerin eğitiminin ihmal edilmiş olması bilinen bir gerçektir (Ataman, 2012; 2014). İhmal edilmiş olmasının yanı sıra yanı sıra bürokrasinin vizyonu, birikimi ve düşünceleri de önemlidir. İlk olma ve ilk defa gerçekleştirme çabalarının geçmişte var olan çalışmaları göz ardı ettiği ve var olan çalışmaların sürdürülebilirliğini de engellediği düşünülebilir. Diğer taraftan gerek MEB'in kendi içinde ve gerekse bakanlıklar arası veya sivil toplum kuruluşları, üniversiteler ile koordinasyonun çeşitli nedenlerden dolayı sağlıklı kurulamaması da özel yetenekli bireylerin eğitiminin önündeki engeller arasında sayılabilir. Ülkemizde insanların özel yetenekli bireylere ilişkin algılarının da politika belirlemede etkili olabileceği gerçeğinden hareketle Sak (2011) tarafından yapılan bir araştırmayı paylaşmakta fayda var. 812 katılımcı ile gerçekleştirilen çalışmada elde edilen bulgulardan biri de özel yetenekli bireylerin ruhsal ve davranışsal problemlerinin olduğudur $(\% 60,5)$. Ayrıca aynı araştırmacı bu durumun özellikle medyada yansıtılma biçiminden kaynaklandığını öne sürmektedir.

Hükümetlerin kalıcılıklarını sağlamak ve bir sonraki seçim dönemine ilişkin topluma vaat edilenlerin gerçekleştirilmesi kaygıları bürokratları uzun vadeli politikaların belirlenmesi ve uygulanmasına ilişkin yaklaşımlardan uzak tuttuğu düşünülebilir. Nitekim Çoban (2016) tarafından yapılan doktora tezinin bir bölümünü MEB'teki yeniden yapılanmayı değerlendirme oluşturmaktadır. Bu amaçla dört müsteşar yardımcısı ve dört genel müdür ile ve ayrıca dokuz kişilik bir grupla (2 şef, 1 görevli öğretmen, 2 eğitim uzmanı, 1 şube müdürü, 1 MEB eğitim uzman yardımcısı, 1 maarif müfettişi, 1 daire başkanı) odak görüşmesi yapmıştır. Yapılan içerik analizi sonucunda değişim sürecinde kaygı ortamının hâkim olduğu ve güven ortamının oluşturulamadığı, kurumsal hafızanın sekteye uğradığ 1 ve değişimi takip etmek amacıyla etkili bir izleme değerlendirme mekanizmasının kurulamadığı elde edilen bazı temalardır.

Bu çalışmada Cumhuriyetin kuruluşundan günümüze kadar düzenlenen toplam 19 millî eğitim şûrasında özel yetenekli bireylerin eğitimine ilişkin alınan kararlar incelenmiştir. Yapılan incelemede tek partili dönemde düzenlenen şûralar, çok partili döneme geçiş sürecinde düzenlenen şûralar, çok partili dönemde düzenlenen şûralar, planlı dönemde düzenlenen şûralar, 1980 sonrası düzenlenen şûralar sınıflaması temel alınmıştır (Deniz, 2001). Yazarlar tarafından da 2000 yılından sonrası olmak üzere 2000 sonrası düzenlenen şûralar adı altında altıncı dönem eklenmiştir.

Millî Eğitim Bakanlığı'nca (MEB) 2013 yılında yayımlanan strateji ve uygulama planında (MEB, 2013) ilk defa özel yetenekli birey kavramının kullanılmaya başlandığı görülmektedir. Daha sonra 2015 ve 2016 yılında yayımlanan bilim ve sanat merkezleri (BİLSEM) yönergelerinde (MEB, 2015a, 2016) ve 2018 yılında yayımlanan özel eğitim hizmetleri yönetmeliğinde (MEB, 2018a) aynı kavramın kullanıldığı görülmektedir. Bugün artık bürokraside ve üniversitelerde de aynı kavramın kullanıldığı bilinmektedir. Plan, yönerge ve yönetmeliğe bakıldığında tanımın içeriğinin 2013 yılından önce yayımlanan belgelerle aynı olduğu ancak kavramın (üstün yetenek, üstün özel yetenek, özel yetenek) değiştiği görülmektedir. Özel yetenek kavramının kullanılmasının, etiketleme, fırsat eşitliği ve elitizm oluşturma kaygısından kaynaklandığı düşünülebilir (TBMM, 2012). 


\section{Millî Eğitim Şûrası ve Kararları}

MEB, Cumhuriyetin kuruluşundan itibaren eğitimle ilgili karşılaştığı önemli sorunları çözmek ve eğitimin planlanması amacıyla 22 Haziran 1933 tarih ve 2287 sayılı kanun ile kurulan ve daha sonra MEB'in daimî kurumları arasına yer alan MEB'in danışma organı olan millî eğitim şûrasını teşkilatına eklemiştir (Dinç, 2008). 22 Haziran 1933 tarihli ve 2434 sayılı Resmî Gazete'de kurulması ile ilgili maddeler aşağıdadır (MEB, 1933).

Madde 3 - Maarif şûrası Cumhuriyet maarifinin terbiyeye tedrisata taallûk eden işlerinde talim ve terbiye dairesince hazırlanacak nizamname, talimatname, program ve esaslarla şûra azası tarafindan bu mevzular etrafinda yapılacak teklifleri tetkik ederek bir karara bağlar. Maarif şûrasının kararları Maarif Vekilinin tasdikiyle katileşir.

Madde 4 - Maarif şûrası şu zatlardan terekküp eder:

I) Maarif müsteşarı,

2) Millî Talim ve terbiye dairesi reis ve azaları,

3) Darülfünun emini ve darülfünunun her fakültesi ile güzel sanatlar akademisinin her şubesinden ve Maarif Vekâletine bağh yüksek mekteplerin muallim meclislerince seçilecek birer müderris veya muallim,

4) Tedrisat umum müdürleri ve kütüphaneler, müzeler müdürleri ile mektep müzesi müdürü,

5) Müfettişlerce kendi aralarmdan seçecekleri iki müfettiş,

6) Maarif müdürlerinden Vekâletçe seçilecek iki zat,

7) Her lise ile muallim mekteplerinin muallim meclislerince gösterilecek birer namzetten vekâletçe seçilecek üçer zat,

8) Maarif müdürlerince gösterilecek birer namzet arasından Vekâletçe seçilecek iki ilk tedrisat müfettiş ve üç ilk mektep muallimi,

9) İhtisaslarından istifade olunmak üzere Vekâletçe davet olunacak yedi zat, Şûraya seçki ile gelen zatlar her üç senede bir seçilirler. Şûranın reisi Maarif vekilidir.

Madde 5 - Maarif şûrası üç senede bir defa toplanır. Ancak lüzumu halinde Maarif Vekili Şûrayı fevkalâde toplantıya da davet edebilir.

Madde 6 - Maarif şûrasının ruznamesi vekâletçe hazırlanarak toplantıdan en az bir ay evvel azaya bildirilir.

1988, 1993, 1995 ve 2014 yıllarında yeniden düzenlenen millî eğitim şûrası (MEB, 2014a); en yüksek danışma kurulu olduğu, 4 yılda bir toplandığı, alınan ve kabul edilen kararların yönetmelikle yayımlandığı ve tavsiye niteliğinde olduğu görülmektedir.

Şûra

MADDE 5-(1) Şûra; Bakanlığın en yüksek danışma kuruludur. Türk millî eğitim sistemini geliştirmek, niteliğini yükseltmek için eğitim ve öğretimle ilgili konuları tetkik eder; tavsiye kararları alır.

Şûranın teşkili

MADDE 6 - (1) Bakan, Şûranın tabii üyesi ve başkanıdır. Şûra, tabii üyeler ile davetli üyelerden teşekkül eder.

Şûranin toplanması

MADDE 11 - (1) Şûranın, Bakanın daveti üzerine 4 yılda bir toplanması esastır. Bakan, gerektiğinde Şûrayı olağanüstü toplantıya çă̆ırabilir.

Şûra gündemi

MADDE 12 - (1) Şûranın gündemi ve toplantı tarihi, doğrudan Bakan tarafından tespit edilebilir ya da Kurul tarafindan belirlenerek Bakana sunulur. Gündemin belirlenmesinde merkez ve taşra birimleriyle diğer kurum ve kuruluşlarm görüşleri de alnnabilir.

Şûra kararlarının kabulü 
MADDE 17 - (1) Kararlar, toplantıya katılan üyelerin oy çokluğu ile alınır. Oylamalar açık tasnif usulüyle yapılır. Oyların eşit olması hâlinde Başkanın katıldığı görüş kabul edilir.

Şûra kararlarının yayımlanması

MADDE 18 - (1) Şûra Genel Kurulunda alınan kararlar Bakan oluru ile Tebliğler Dergisinde yayımlanir.

Şûra kararlarımın uygulanması

MADDE 19 - (1) Şûra kararları tavsiye niteliğindedir. Genel Sekreterlik, Şûra kararlarını ilgili birimlere gönderir.

Şûranin sekreterya işleri

MADDE 20 - (1) Şûranın sekreterya işleri Kurul Başkanlığınca yürütülür.

14/09/2011 tarihli ve 28054 sayılı Resmî Gazete'de 652 sayılı “Millî Ĕ̆itim Bakanlığının Teşkilat ve Görevleri Hakkında Kanun Hükmünde Kararname"nin yayımlanması ile birlikte yeniden yapılanma sürecinde MEB, Talim ve Terbiye Kurulu Başkanlığı'nda Kurul ve Şûra İşleri Daire Başkanlığını kurmuştur (MEB, 2017a). Kurulan başkanlığın görevleri ise şunlardır: "Kurul çalı̧̧maları ile ilgili iş ve işlemleri yapmak, Millî eğitim şûrası ile ilgili iş ve işlemleri yapmak, Kurul ve Şûra çalışmaları için dokümantasyon ve kaynak taraması yapmak, Başkan tarafindan verilen diğer görevleri yapmak" tır.

Millî eğitim şûrası, kanunda belirtilen konumu gereğince bir danışma ve planlama kuruludur. Burada yapılan çalışma sonucunda hazırlanan raporlar genel kurulda onaylanır veya değiştirilir. Onaylanan kararlar şûra kararı olarak MEB'e tavsiye niteliğindedir (Dinç, 2008). Tavsiye niteliğinde olmasına rağmen şûralarda alınan kararlar MEB'in politika belirlemesinde önemli rol oynamaktadır. Nitekim 2017 yılında talim ve terbiye kurulunca hazırlanan müfredatta, yenileme ve değişiklik çalışmalarına bakıldığında referans alınan önemli dokümanlarından birini de şûralarda alınan kararlar oluşturmaktadır (MEB, 2017b).

\section{Şûralar}

Şûralar, MEB'in önemli en üst kurulu ve danışma organıdır. Şûra kararları MEB'in ilgili birimleri açısından bağlayıcı olmamakla beraber zaman zaman yöneticilerin önemli buldukları kararları uygulamaya koydukları kararlardır (Can, 1999). Şûralar ve şûralarda alınan kararların tavsiye niteliğinde olması ve MEB politikalarına dayanak oluşturması bakımından önemli olup, şûralarla ilgili tez ve makale çalışmalarının yapıldığı görülmektedir. Örneğin, Can (1999), Deniz (2001), Gümüşgül ve Göral (2014), Güven (2016), Güzel ve Şimşek (2012), Memduhoğlu ve Taymur (2014), Tofur, Aypay ve Yücel (2016) ve Uzun ve Üstten (2010) tarafından yapılan çalışmalar bazılarıdır.

\section{Yöntem}

1923 yılından günümüze kadar düzenlenen 19 millî eğitim şûrası dokümanları incelenmesi amacıyla ile gerçekleştirilen söz konusu araştırmada nitel araştırma yöntemi kullanılmıştır. Creswell (1998) nitel araştırmayı, sosyal yaşamı ve insanla ilgili problemleri kendine özgü yöntemlerle sorgulayarak, anlamlandırma süreci olarak ifade etmektedir. Genel itibari ile nitel araştırmacı gözlem, görüşme ve dokümanlardan yola çıkarak kavramları, anlamları ve ilişkileri açılamaktadır (Merriam, 1998). 
Araştırmacılardan birinin uzun yıllar özel yeteneklilerin eğitimi alanında kamuda uzman ve yöneticilik yapmış olması ve diğer bir araştırmacının da aynı alanda uzun yıllar çalışmış olması, MEB ve TÜBİTAK (Türkiye Bilimsel ve Teknolojik Araştırma Kurumu) işbirliği içerisinde yürütülen projelerde ve bilimsel çalışmalarda görev almış olması ayrıca önem taşımaktadır.

\section{Verilerin Toplanması}

Çalışmada nitel araştırma yöntemlerinden doküman incelemesi yoluyla veriler toplanmıştır. Doküman incelemesinde, araştırılması hedeflenen olgu veya olgular hakkında bilgi içeren yazılı dokümanların analizi yer almaktadır (Yıldırım ve Şimşek, 2013). Doküman incelemesinde şûra kararların değerlendirilmesi sürecinde, bugüne kadar düzenlenen şûraların belirlenmesi, düzenlenen şûra kararlarında alınan kararlara ulaşılması ve alınan kararların uygulanmasına yönelik bağlamında değerlendirilmesi aşamaları izlenmiştir. Bu kapsamda çalışmada, şûralarda alınan kararların ülkemizde özel eğitim politikaları oluşturmada etkin olduğu varsayımından hareketle özel yetenekli bireylerin eğitimi gözden geçirilmiştir.

1923 yılından günümüze kadar düzenlenen şûralar incelenmiştir. Yıllara göre düzenlenen şûralar Tablo 1'de yer almaktadir.

Tablo 1. Yıllara Göre Düzenlenen Şûra Sayısı

\begin{tabular}{cccccc}
\hline $1923-1938$ & $1938-1950$ & $1950-1960$ & $1960-1980$ & $1980-2000$ & $2000-2017$ \\
- & 4 & 2 & 3 & 7 & 3 \\
\hline
\end{tabular}

Tablo 1'de görüldüğgü üzere, 79 yıl içinde toplam on dokuz şûranın yapıldığı, ortalama 4 yılda bir şûranın yapıldığı ve 1980-2000'li yıllar arasında yedi şûranın yapıldığı dikkat çekmektedir. Düzenlenen toplam on dokuz şûraya ilişkin ise bazı bilgiler Tablo 2' de yer almaktadır.

Tablo 2. Düzenlenen Şûralara İlişkin Bazı Bilgileri

\begin{tabular}{|c|c|c|c|c|c|}
\hline & Yili & $\begin{array}{c}\text { Katılımc1 } \\
\text { Sayısı }\end{array}$ & $\begin{array}{c}\text { Komisyon } \\
\text { Say1s1 } \\
\end{array}$ & Bakan & Hükümetler \\
\hline \multicolumn{6}{|c|}{ Tek Partili Dönemde Düzenlenen Şûralar (Deniz, 2001) } \\
\hline I. & 17 - 29 Temmuz 1939 & 138 & 8 & Hasan Ali Yücel & $\begin{array}{l}\text { İsmet İNÖNÜ } \\
\text { 8. Hükümet }\end{array}$ \\
\hline II. & 15 - 21 Şubat 1943 & 142 & 3 & Hasan Ali Yücel & $\begin{array}{l}\text { Şükrü } \\
\text { SARAÇOĞLU } \\
\text { 13. Hükümet }\end{array}$ \\
\hline \multicolumn{6}{|c|}{ Çok Partili Döneme Geçiş Sürecinde Düzenlenen Şûralar } \\
\hline III. & 2 - 10 Aralık 1946 & 292 & 5 & $\begin{array}{l}\text { Reşat Şemsettin } \\
\text { Sirer }\end{array}$ & $\begin{array}{l}\text { Mehmet Recep } \\
\text { PEKER } \\
\text { 15. Hükümet }\end{array}$ \\
\hline IV. & 22 - 31 Ağustos 1949 & 271 & 5 & Tahsin Banguoğlu & $\begin{array}{l}\text { Şemsettin } \\
\text { GÜNALTAY } \\
\text { 18. Hükümet }\end{array}$ \\
\hline \multicolumn{6}{|c|}{ Çok Partili Dönemde Düzenlenen Şûralar } \\
\hline V. & 5 - 14 Şubat 1953 & 326 & 8 & Tevfik İleri & $\begin{array}{l}\text { Adnan MENDERES } \\
\text { 20. Hükümet }\end{array}$ \\
\hline VI. & 18 - 23 Mart 1957 & 550 & 4 & Ahmet Özel & $\begin{array}{l}\text { Adnan MENDERES } \\
\text { 22. Hükümet }\end{array}$ \\
\hline
\end{tabular}


Tablo 2 (devamı). Düzenlenen Şûralara İlişkin Bazı Bilgileri

\begin{tabular}{|c|c|c|c|c|c|}
\hline & Y1li & $\begin{array}{c}\text { Katılımc1 } \\
\text { Sayı1sı }\end{array}$ & $\begin{array}{c}\text { Komisyon } \\
\text { Say1S1 } \\
\end{array}$ & Bakan & Hükümetler \\
\hline \multicolumn{6}{|c|}{ Planlı Dönemde Düzenlenen Şûralar } \\
\hline VII. & 5 - 15 Şubat 1962 & - & 14 & Hilmi İncesulu & $\begin{array}{l}\text { İsmet İNÖNÜ } \\
\text { 26. Hükümet }\end{array}$ \\
\hline VIII. & 28 Eylül - 3 Ekim 1970 & 126 & 2 & Orhan Oğuz & $\begin{array}{l}\text { Süleyman } \\
\text { DEMİREL } \\
\text { 32. Hükümet }\end{array}$ \\
\hline IX. & 24 Haziran - 4 Temmuz 1974 & - & 2 & Mustafa Üstündağ & $\begin{array}{l}\text { Bülent ECEVİT } \\
\text { 37. Hükümet }\end{array}$ \\
\hline \multicolumn{6}{|c|}{1980 Sonrası Düzenlenen Şûralar } \\
\hline $\mathrm{X}$. & 23 - 26 Haziran 1981 & 180 & 4 & Hasan Sağlam & $\begin{array}{l}\text { Bülent ULUSU } \\
\text { 44. Hükümet }\end{array}$ \\
\hline XI. & 8 - 11 Haziran 1982 & - & 1 & Hasan Sağlam & $\begin{array}{l}\text { Bülent ULUSU } \\
\text { 44. Hükümet }\end{array}$ \\
\hline XII. & 18 - 22 Haziran 1988 & - & 7 & Hasan Celal Güzel & $\begin{array}{l}\text { Turgut ÖZAL } \\
\text { 46. Hükümet }\end{array}$ \\
\hline XIII. & 15 - 19 Ocak 1990 & - & 4 & Avni Akyol & $\begin{array}{l}\text { Yıldırım AKBULUT } \\
\text { 47. Hükümet }\end{array}$ \\
\hline XIV. & 27 - 29 Eylül 1993 & - & 2 & Nahit Menteşe & $\begin{array}{l}\text { Tansu ÇİLLER } \\
\text { 50. Hükümet }\end{array}$ \\
\hline XV. & 13 - 17 Mayıs 1996 & - & 5 & Turhan Tayan & $\begin{array}{l}\text { Mesut YILMAZ } \\
\text { 53. Hükümet }\end{array}$ \\
\hline XVI. & 13 - 17 Kasım 1999 & - & 5 & Metin Bostancığlu & $\begin{array}{l}\text { Bülent ECEVİT } \\
\text { 57. Hükümet }\end{array}$ \\
\hline \multicolumn{6}{|c|}{2000 Sonrası Düzenlenen Şûralar } \\
\hline XVII. & 13 - 17 Kasım 2006 & 850 & 2 & Hüseyin Çelik & $\begin{array}{l}\text { Recep Tayyip } \\
\text { ERDOĞAN } \\
\text { 59. Hükümet }\end{array}$ \\
\hline XVIII. & 1 - 5 Kasım 2010 & - & 5 & Nimet Çubukçu & $\begin{array}{l}\text { Recep Tayyip } \\
\text { ERDOĞAN } \\
\text { 60. Hükümet }\end{array}$ \\
\hline XIX. & 2 - 6 Aralık 2014 & 600 & 4 & Nabi Avcı & $\begin{array}{l}\text { Ahmet } \\
\text { DAVUTOĞLU } \\
\text { 62. Hükümet } \\
\text { (Başbakanlık, 2017) }\end{array}$ \\
\hline
\end{tabular}

Şûralar, 1921 yılında Maarif Kongresi, 1923, 1924, 1925 ve 1926 yıllarında "Heyet-i İlmîye", 1939, 1943, 1946, 1949, 1953, 1957, 1962, 1970, 1974, 1981, 1982, 1988, 1990, 1993, 1996, 1999, 2006, 2010 ve 2014 yıllarında “Millî Eğitim Şûraları" adı altında yapılmıştır (Uzun ve Üstten, 2010). Tablo 2'de, şûraların düzenlendiği tarih, katılımcı sayısı, düzenlendiği yer, oluşturulan komisyon sayısı ve o dönemde görevde bulunan MEB Bakanının adı yer almaktadır. Şûraların, planlı dönemde düzenli bir şekilde yapılamadığı ve bazı şûralar arasındaki sürenin (XI. ve XII.) uzun olduğu görülmektedir. I., II. ve X., XI. şûralarda Millî Eğitim Bakanının aynı olduğu, diğer tüm şûralarda Millî Eğitim Bakanlarının farklı olduğu dikkat çekmektedir. 1980 sonrası X. ve XI. şûraların ise ardı ardına yapıldığı dikkatlerden kaçmamaktadır. 1939-1961 yılları arasında ise altı şûranın yapıldığı görülmektedir. Eriş (2006) tarafından yapılan yüksek lisans tezinde, bu dönemde alınan kararların hemen hemen hepsinin uygulamaya geçirilmesinin eğitim açısından önemli olduğu ve şûralar açısından en verimli dönemin 1939-1961 yıllarını kapsayan dönem olduğu ifade edilmektedir. 
Ülkemizde özel yetenekli bireylerin eğitimi politikalarına ilişkin çalışmalara bakıldığında genellikle çeşitli dokümanların bulunduğu ancak var olan dokümanların analizine ve millî eğitim şûrasında alınan kararların politikaya yansımasına ilişkin yeterli çalışmaların olmadığı görülmüştür. $\mathrm{Bu}$ açıdan değerlendirildiğinde söz konusu çalışmada millî eğitim şûralarında alınan kararlar değerlendirilmiş ve politikalara yansımalarına bakılmıştır.

\section{Millî Eğitim Şûralarında Alınan Kararların Değerlendirilmesi}

Cumhuriyetin kuruluşundan günümüze kadar düzenlenen on dokuz millî eğitim şûrasının gündem maddelerinde, ağırlıklı olarak; mesleki ve teknik eğitim, ilköğretim ve ortaöğretim programları, yükseköğretim, öğretmen yetiştirme ve mevzuata ilişkin çalışmaların yoğunlukta olduğu görülmektedir. Tofur, Aypay ve Yücel (2016) tarafından yapılan çalışmada, 1980 yılı sonrası düzenlenen dokuz şûrada (1980-2014) en çok çalışılan başlıklardan birinin çalışma koşullarımı geliştirme ve en az çalış1lan başlıklardan birinin ise öğretmen öğrenmeleri ve öğrenci başarısını değerlendirme boyutu olduğu bulunmuştur. Çakır (2017) tarafından yapılan bir başka çalışmada ise, 1980 sonrası düzenlenen şûralarda eğitim politikaları ile ilgili 21 kavram tespit edilmiştir. En fazla tartışma konusu yapılanlar ise sirasıyla; ögrretmen, mesleki ve teknik eğitim, okul öncesi eğitim, ilköğretim, özel eğitim, yaygin eğitim, teknoloji kullanımı, özel sektör, zorunlu eğitim, yabancı dil ve Atatürkçülük konularının olduğu görülmüştür.

\section{Tek Partili Dönemde Düzenlenen Şûralar}

1939 ve 1943 olmak üzere toplam iki şûranın düzenlendiği dikkat çekmektedir. Düzenlenen şûralarda daha çok bakanlığın plan ve esasları, müfredatın gözden geçirilmesi, anadil çalışmaları, ahlak gelişimi, program ve yönetmeliklerin hazırlanması, öğretmen yetiştirme politikaları vb. temel politikalara ilişkin gündem maddelerinin olduğu göze çarpmaktadır.

\section{Çok Partili Döneme Geçiş Sürecinde Düzenlenen Şûralar}

Özel gereksinimli çocukların eğitimi politikalarına ilişkin ilk şûra kararlarının, çok partili döneme geçiş sürecinde düzenlenen IV. Millî Eğitim Şûrasında (1949) alındığı ve ilk defa zihinsel yetersizliği olan öğrenciler ile özel yetenekli çocukların eğitiminin ayrı okullarda verilmesi yönünde bir önerinin getirildiği ancak getirilen önerinin kabul görmemesi nedeni ile talim ve terbiye kuruluna havale edildiği görülmektedir (Deniz, 2001).

\section{Çok Partili Dönemde Düzenlenen Şûralar}

Çok partili dönemde düzenlenen V. Millî Eğitim Şûrasında (MEB, 1953), özel gereksinimli çocukların eğitimine ilişkin okulların açılması gündeme gelmiş ve korunmaya muhtaç çocuklar hakkındaki kanunun yeniden gözden geçirilmesi kararlaştırılmıştır. Kararlaştırılan kanunun yeniden gözden geçirilmesi özel yetenekli çocukları kapsamamaktadır. Dönemin şartları değerlendirildiğinde daha çok korunmaya muhtaç ve özel gereksinimli çocukların sağlık ve bakım giderleri üzerinde durulduğu görülmektedir. İlk defa özel eğitime gereksinimi olan çocukların ihtiyaçları doğrultusunda bir rapor hazırlanmış ve rapor şûra gündemi maddeleri arasında yer almıştır. 1953 yılında düzenlenen V. Millı̂ Eğitim Şûrasında yer verilen ve kabul edilen bir öneride şöyledir: “Güzel 
sanatlarda olağanüstü yetenek gösteren çocukların devlet tarafindan yetiştirilmesi 6610 sayılı kanunda kabul edilmekte denilerek zekâ ve teknik alanda olağanüstü yetenekli çocukların da bu kanun kapsamına alınması"dır. 12/07/1948 tarihli ve 6955 sayılı Resmî Gazete'de 5245 sayılı "İdil Biret ve Suna Kan'ın Yabancı Memleketlere Müzik Tahsiline Gönderilmesine Dair Kanun", diğer adı ile İdil Biret ve Suna Kan yasası bunlardan biridir. Yasa kapsamında yurt dışına gönderilen İdil Biret ve Suna Kan, ülkemizde ve yurt dışında birçok başarıya imza atmışlardır (Tunçdemir, 2008). Daha sonra söz konusu yasa genişletilerek 24/02/1956 tarihli ve 9242 sayılı Resmî Gazete'de 6660 sayılı “Güzel Sanatlarda Fevkalade İstidat Gösteren Çocukların Devlet Tarafından Yetiştirilmesi Hakkında Kanun" yayımlanmıştır. 1963 yılında da söz konusu kanuna dayanılarak 05/08/1963 tarihli ve 11472 sayılı Resmî Gazete' de “Güzel Sanatlarda Fevkalâde İstidat Gösteren Çocuklarnn Devlet Tarafindan Yetiştirilmesi Hakkındaki Yönetmelik" yayımlanmıştır (Akkanat, 2004). Müzik ve plastik sanatlarda olağanüstü yetenekleri olan çocukların yurt içi ya da yurt dışında devlet hesabına yetiştirilmelerine ilişkin uygulanmakta olan 6660 Sayılı Yasanın 1956-1972 yılları arasında yararlananların tümünün büyük kentlerde oturan sanatkâr, öğretmen ve aydın ailelerden geldikleri ve ayrıca ailelerinde kendilerine benzer kişilerin olduğu da ortaya çıkmıştır (Güzel, 1973).

\section{Planlı Dönemde Düzenlenen Şûralar}

1957 yılında Sovyetler Birliği tarafından fırlatılan Sputnik füzesinin dünyada özel yeteneklilerin eğitiminde bir milat olarak kabul edildiği görülmektedir. Planlı dönemde düzenlenen VII. ve IX. Millî Eğitim Şûralarına bakıldığında (MEB, 1962; 1974), ülkemiz de dünyadaki gelişmelere kayıtsız kalmamış ve planlı dönemde düzenlenen VII. Millî Eğitim Şûrasında özel yetenekli çocukların eğitimine yönelik liselerin kurulması çalışmaları gündeme gelmiş ve fen liselerinin açılma süreci başlamıştır. VII. Millî Eğitim Şûrasının önemli maddelerinden bir diğeri de, lise ve dengi meslek okullarını bitiren öğrencilerin ilgili fakültelere giriş hakkını elde edebilmek için yetiştirildikleri alanlara göre tek elden idare olunacak çeşitli olgunluk imtihanlarına yer verilmesi düşüncesidir. 1960'lı yıllara gelinceye kadar lise mezunu sayısının az olması nedeniyle üniversitelerin başvuran öğrencileri sınavsız kabul ettiği, 1960'lı yıllardan sonra lise mezunundaki sayının artması sonucunda üniversitelerin kendi amaçları doğrultusunda sınavlarını yaptıkları ancak daha sonraki yıllardaki mezun sayısındaki artış ve objektifliğin sağlanabilmesi gibi çeşitli nedenlerden dolayı 1974 yılında Ö̆̆grenci Seçme ve Yerleştirme Merkezi'nin (ÖSYM) kurulduğu görülmektedir (ÖSYM, 2017). Söz konusu süreç ile birlikte dershane sürecinin de başladığı söylenebilir.

Cumhuriyetin kuruluşundan günümüze kadar gelişmelere bakıldığında sanat eğitimine önem verildiği görülmektedir. VII. Millı̂ Eğitim Şûrasında Deneme Sanat Enstitüsü kurulması düşüncesi ortaya atılmıştır. Ülkemizin Cumhuriyetin kuruluş yıllarında sanat eğitimi üzerinde durma düşüncesi, yeteneğin daha kolay tanılanabilir olması düşüncesinden kaynaklanmış olabilir (TBMM, 1967). Planlı dönemde düzenlenen IX. Millî Eğitim Şûrasında, özel eğitim, özel yetenek vb. kavramların yer almadığı ancak önemli kavramlar arasında yer alan bireysel farklılıklar kavramının yer aldığ ve bireysel farklılıklar dikkate alınarak eğitimde fırsat eşitliği çerçevesinde ilgi ve yetenek grupları doğrultusunda eğitim düzenlemelerinin yapılması ifadelerine yer verildiği görülmüştür. 


\section{Sonrası Düzenlenen Şûralar}

1980'li yıllardan sonra düzenlenen VII., IX., XI., XII., XVII., XVIII. ve XIX. şûralarda, özel yeteneklilerin eğitimine ilişkin önemli kararların alındığı ancak alınan kararların uygulamada çok az yer bulduğu veya hiç bulmadığı ve son yıllarda özel gereksinimli çocukların eğitimi alanında ilerlemelere rağmen aynı ilerlemenin özel yeteneklilerin eğitimi alanında olmadığı görülmektedir. Şüphesiz kararların uygulanmamasında ve ilerlemenin kaydedilememesinde çeşitli nedenler dışında özel yeteneklilerin eğitiminin özel eğitim kapsamında değerlendirilmemesi de sayılabilir.

1980 sonrası düzenlenen XI. Millî Eğitim Şûrasında (MEB, 1982) dikkat çeken nokta tek bir gündem maddesi (öğretmen ve eğitim uzmanı durum, yetiştirilmeleri ve öneriler) üzerinde yapılmasıdır. XI. Millî Eğitim Şûrasında yer alan maddelerden biri de özel eğitim uzmanının tanımı, görevleri ve eğitimlerine yönelik model önerisidir. Bu kapsamda özel eğitim dallarına bakıldığında özel yeteneklilerin eğitimi de yer almaktadır. Diğer taraftan parantez içinde yer alan sayı (2500) o dönemde özel yeteneklilerin eğitiminde yetiştirilmesi gereken uzman sayısına işaret etmektedir. Özel eğitim alanında özel yetenekli bireylerin eğitiminde görev alacak öğretmenlerin yetiştirilmesinde ise 2000'li yıllara kadar herhangi bir çalışmanın yapılmadığı görülmektedir. 2002 yılında İstanbul Üniversitesi Hasan Ali Yücel Eğitim Fakültesi bünyesinde açılan üstün zekâlılar öğretmenliği sonrasında birkaç özel üniversite de aynı bölüm açılmıştır. Ancak Yükseköğretim Kurulu'nun (YÖK) 2016 yılında aldığı karar sonrasında üniversitelerde bulunan çeşitli bölümler (işitme yetersizliği, görme yetersizliği, üstün zekâlılar vb) özel eğitim çatısı altında birleştirilmiştir.

XII. Millî Eğitim Şûrasında (MEB, 1988), özel gereksinimli çocukların eğitimine önem verilmesi gerektiği üzerinde durulmuştur. Buna göre özel yeteneklilerin eğitiminde özel eğitim sınıflarının açılması kararı alınmıştır. Ancak bugüne gelindiğinde özel yeteneklilerin eğitimi için özel eğitim sınıflarının açılamadığı görülmektedir. Bugün MEB'in uygulamalarına bakıldığında da BİLSEM uygulamaları ve kısmen de destek eğitim odası uygulamalarının olduğu görülmektedir.

XII. Millî Eğitim Şûrasında alınan bir diğer kararda özel yetenekli çocuklarında özel programlarla yetiştirilmesidir. Bu karar doğrultusunda 1989 yılından itibaren güzel sanatlar liseleri açılmaya başlanmıştır. Onu daha sonra ne kadar dayanak teşkil ettiği tartışılabilir olmakla beraber 1995 yılında BİLSEM'in açılması, 2003 yılında sosyal bilimler lisesinin açılması ve 2009 yılında ise spor lisesinin açılması takip etmiştir. Bugün matematik, fen, Türkçe, sosyal, resim, müzik ve spor alanında yetenekli olan öğrencilere yönelik ortaöğretim düzeyinde okullar bulunmaktadır. Ancak temel eğitim düzeyinde okulların bulunmadığı, bu düzeydeki özel yetenekli çocukların daha çok BİLSEM'e devam ettiği görülmektedir. Yapılan araştırmalarda BİLSEM'den daha çok temel eğitime devam eden öğrencilerin yararlandığı bulunmuştur (Bilgiç, 2017).

Fen liseleri ve sosyal bilimler liselerinin nitelikleri tartışılmakla beraber, MEB'in kurum açma 
yönetmeliğinde, bir ilde sekizinci sınıfta okuyan toplam öğrenci sayısının \%5'ini geçmeyecek şekilde fen lisesi ve sosyal bilimler lisesi açılma kriteri belirlenmiştir (MEB, 2017c). Örneğin Bartın ilinde ortaokula giden öğrenci sayısı 10.310'dur (MEB, 2017d). Adı geçen yönetmeliğe göre \%5'i alınan 515 öğrencinin fen ve sosyal bilimleri lisesine gidebileceği varsayılmaktadır. Bu da Bartın ili için bir fen lisesi veya bir sosyal bilimler lisesi anlamı taşımaktadır. \%5'lik bir oran ile yapılacak düzenlemeye göre fen ve sosyal bilimler lisesinin açılmasının daha sağlıklı bir uygulama olacağ değerlendirilmektedir.

XII. Millı̂ Eğitim Şûrasında alınan önemli kararlardan bir diğeri de özel eğitim alanının ihtiyaç duyduğu öğretmenlerin yetiştirilmesine yönelik düzenlemedir. Daha önce de zaman zaman gündeme gelen ve ilk defa XI. Millî Eğitim Şûrasında ayrıntılandırılan öğretmen yetiştirme politikasında bugüne gelindiğinde, özel eğitimde görme, işitme ve zihinsel alanda öğretmen yetiştirmede yol alındığı ancak özel yetenek alanında öğretmen yetiştirilmesinde ise aynı hızda yol alınamadığı gerçeğidir. Son yıllarda yapılan çalışmalar ile özel yetenek alanında öğretmen yetiştirme çabaları devam etmektedir.

\section{Sonrası Düzenlenen Şûralar}

2000 yılı sonrası düzenlenen XVII. Millî Eğitim Şûrası (MEB, 2006a), Cumhuriyet tarihinden günümüze kadar özel yeteneklilerin eğitimi alanında ayrıntılı kararların alındığı ilk şûra olma özelliği taşıması açısından önemlidir. 2006 yılında düzenlenen XVII. Millî Eğitim Şûrasında alınan kararlardan biri "17. Üstün zekâlı çocukların eğitimi ve istihdamı konularında politikalar oluşturulmalıdır" maddesidir. Bu tarihten itibaren MEB'in özel yetenekli bireylerin eğitimine yönelik politika oluşturma sürecine girdiğini görmekteyiz. 2011 yılında yayımlanan 652 sayılı kanun hükmünde kararname öncesi özel yeteneklilerin eğitimi, şube müdürlüğü düzeyinde temsil edilmekte iken 2011 yılından sonra MEB' in yeniden yapılanma sürecinde grup/daire başkanlığı düzeyinde temsil edilmeye başlanmıştır. 05 Ağustos 2009 tarihli ve 27310 sayılı Resmî Gazete'de yayımlanan Bilim ve Teknoloji Yüksek Kurulunun Onsekizinci ve Ondokuzuncu Toplantısı ile ilgili 2009/16 sayılı Başbakanlık Genelgesinde, ülkemizde özel yetenekli bireylerin eğitimine yönelik MEB koordinasyonunda “Üstün Yetenekli Bireyler Strateji ve Uygulama Planı 2009-2013"ün hazırlanmasına ilişkin çalışmaların başlatılmasına karar verilmiştir. Karar sonrası yapılan çalışmalar sonucunda hazırlanan “Özel Yetenekli Bireyler Strateji ve Uygulama Planı 2013-2017”, 2013 yılında Bilim ve Teknoloji Kurulu'nun (BTYK) yirmi beşinci toplantısında sunularak yayımlanmıştır.

Strateji planında özel yeteneklilerin eğitimine yönelik yapılması gerekenler Tablo 3'te özet halinde yer almaktadır (MEB, 2013). Strateji planının yayımlanmasındaki temel amaç; özel yeteneklilerin eğitimi felsefesini oluşturmak ve toplumdaki anlayışı geliştirmek; alınacak kararlarda ve yapılacak uygulamalarda süreklilik ve fırsat eşitliği sağlamaktır. Tablo 3'te görüldüğü üzere tanılamada, okul öncesi ve ilkokulda gelişim testlerine, ortaokul ve lisede zekâ testlerine ve her kademede öğrenci kişisel dosyalarına yer verilmektedir. Ayrıca okula erken başlatma ve sınıf atlatma okul öncesi dışında tüm eğitim kademelerinde yapılabilmektedir. Zenginleştirme uygulamalarına her kademede, mentörlük uygulamalarına ise sadece lisede yer verildiği görülmektedir. Özel yeteneklilerin eğitiminde, ortaokul ve lisede; BİLSEM, eğitim bölgeleri yetenek grupları, fen liseleri, sosyal 
bilimler liseleri, güzel sanatlar liseleri ve spor liseleri gibi ayrı okul uygulamalarının önerildiği görülmektedir.

Tablo 3. Özel Yetenekli Bireyler İçin Eğitim Düzeylerine Göre Yeni Uygulama Modelleri

\begin{tabular}{|c|c|c|c|c|c|}
\hline \multirow{2}{*}{\multicolumn{2}{|c|}{ Planlanan Uygulamalar }} & \multicolumn{4}{|c|}{ Eğitim Düzeyleri } \\
\hline & & \multirow{2}{*}{$\frac{\text { Okul Öncesi }}{-}$} & \multirow{2}{*}{$\begin{array}{l}\text { İlkokul } \\
-\end{array}$} & \multirow{2}{*}{$\frac{\text { Ortaokul }}{+}$} & \multirow{2}{*}{$\begin{array}{c}\text { Lise } \\
+\end{array}$} \\
\hline 1 & Zekâ Testleri & & & & \\
\hline 2 & Gelişim Testleri & + & + & - & - \\
\hline 3 & Öğrenci Kişisel Dosyaları & + & + & + & + \\
\hline 4 & Hızlandırma (Erken Okula Başlatma ve/veya Sınıf Yükseltme) & - & + & + & + \\
\hline 5 & Kaynaştırma/Bütünleştirme Eğitimi & + & + & + & + \\
\hline 6 & Bireyselleştirilmiş Eğitim Programları & + & + & + & + \\
\hline 7 & Okul İçi Zenginleştirilmiş Destek Programları & + & + & + & + \\
\hline 8 & Okul Dışı Zenginleştirilmiş Destek Programları & + & + & + & + \\
\hline 9 & Yetenek Atölyeleri & - & + & + & + \\
\hline 10 & Destek Eğitim Odaları & + & + & + & + \\
\hline 11 & Eğitim Bölgeleri Yetenek Grupları & - & - & + & + \\
\hline 12 & BİLSEM & - & + & + & + \\
\hline 13 & İleri Düzey Eğitim & - & - & - & + \\
\hline 14 & Uzaktan Eğitim & + & + & + & + \\
\hline 15 & Mentörlük Desteği & - & - & - & + \\
\hline 16 & Aile Eğitim Programları & + & + & + & + \\
\hline 17 & Öğretmenlerin Özel Yetenekler Konusunda Hizmet Öncesi/İçi Eğitimi & + & + & + & + \\
\hline
\end{tabular}

XVII. Millı̂ Eğitim Şûrasında yayımlanan diğer bir kararda "24. Bilim ve sanat merkezlerine öğretmen seçiminde fen lisesi ve Anadolu lisesindeki öğretmen seçimine benzer kriterler getirilmelidir"dir. Söz konusu madde dikkate alınarak 2007 yılında çıkarılan 2007/87 Genelge ile birlikte BİLSEM'e öğretmen seçiminde bu kriterler getirilmiştir. Bugün de halen üzerinde birtakım değişiklikler yapılarak BİLSEM'e öğretmen seçimi yapıldığı görülmektedir. Uygulamada karşlık bulan diğer bir çalışmada "25. TÜBİTAK, Millî Ĕ̆itim Bakanlı̆̆ı ve üniversitelerin iş birliği ile üstün yetenekli öğrencilerin eğitimi konusunda yaz-kış kampları, bilim danışmanlığı vb. etkinliklerin düzenlenmesinde iş birliği yapılmalıdır" maddesidir. Özel yetenekli bireylere yönelik kampların gerek MEB ve gerekse diğer bakanlıklar ve kurumlar tarafından desteklenerek bugün de halen yapıldığı bilinmektedir. Millî eğitim tarihinde ilk defa XVII. Millı̂ Eğitim Şûrasında ayrıntılı tavsiye kararlarının alınması ve alınan tavsiye kararlarının bir kısmının uygulamada yer bulması özel yetenekli bireylerin eğitiminde önemli bir yer tutmaktadır.

2010 yllında düzenlenen XVIII. Millî Eğitim Şûrasında (MEB, 2010) “Üstün yetenekli ve/veya üstün zekâh çocuklarımızın yetenek ve istidatlarına göre programlanmış ve planlanmış özel eğitim okulları açılmalıdır" kararı alınmasına rağmen bugüne kadar herhangi bir adımın atılmadığı söylenebilir. Ülkemizde diğer yetersizlik türlerine (görme, işitme vb.) ilişkin özel eğitim okulları bulunmakta iken özel yeteneklilere ilişkin ayrı okullar bulunmamaktadır. Ortaöğretim düzeyinde bulunan fen ve sosyal bilimler liseleri gibi liselerin mevzuatında gerekli düzenlemeler yapılarak özel eğitim okullarına dönüştürülebilir. Nihayetinde fen ve sosyal bilimler liseleri özel yetenekli öğrencilere yönelik açılan okullardır. Diğer taraftan özel yetenekli çocukların eğitimine ilişkin politikalar farklı genel müdürlükler tarafından belirlenmekte ve az önce sayılan okullar ise farklı genel müdürlüklere bağlı bulunmaktadır. Söz konusu durumun zaman zaman görev karmaşası doğuracağı gerçeğinden hareketle, karmaşanın giderilmesi özel yetenekli çocukların lehine olacaktır. Yine aynı şûrada geçerli ve güvenilir ölçme araçları geliştirilmeli ile ilgili karar değerlendirildiğinde, Sak ve diğerleri 
(2016) tarafından geliştirilen Anadolu Sak Zekâ Ölçeği olumlu bir gelişme olarak değerlendirilmektedir.

2014 yılında düzenlenen XIX. Millî Eğitim Şûrasında (MEB, 2014b) “5. Özel yetenekli öğrencilerin eğitimine yönelik bir yönetmelĭ̆in hazırlanması ve anaokulundan itibaren geçerli olacak şekilde yeni bir öğretim programının yapılması" maddesi yer almaktadır. Özel yetenekli bireylerin eğitiminin özel eğitim kapsamı içerisinde değerlendirilmesi gerçeği göz önüne alınarak ayrı bir yönetmelikte yer verilmesi üzerinde tartışılması gereken konular arasındadır. Kaldı ki 2006 yılında yayımlanan özel eğitim hizmetleri yönetmeliğinde (MEB, 2006b) konuyla ilgili maddeler yer almaktadır. Diğer taraftan hazırlanacak ayrı bir mevzuatın özel yeteneklilerin eğitimini ayrıştıracağı gerçeği de göz önüne alınarak var olan mevzuattaki ilgili maddelerin biraz daha genişletilmesinin soruna çözüm olacağı düşünülmektedir. Yine BİLSEM programı hazırlama çalışmalarının ve ayrıca ilkokul ve ortaokulda destek eğitim odalarına ilişkin ders bazında öğretim programı hazırlama çalışmalarının yapıldığı söylenebilir.

\section{Sonuç ve Öneriler}

Cumhuriyet tarihinden bugüne kadar düzenlenen şûralarda; toplam altı şûrada kararların alındığı, bir şûrada açllış konuşmasında yer verildiği, incelenen ve burada yer verilmeyen 1953, 1981, 1993 ve 1996 yıllarında düzenlenen şûralarda özel eğitime gereksinimi olan çocuklar adı altında tavsiye kararlarına yer verildiği görülmektedir. Diğer taraftan çeşitli tarihlerde düzenlenen şûralarda özel yetenekli bireylerin eğitimine yönelik geniş kapsamlı kararların ilk defa 2006 yılında düzenlenen XVII. Millı̂ Eğitim Şûrasında alındığı ve onu daha sonra 2010 yılında düzenlenen XVIII. Millî Eğitim Şûrası kararlarının izlediği görülmektedir (Sak vd., 2015).

Bugüne kadar düzenlenen şûralarda alınan kararlarda, üstün istidat, üstün zekâ, üstün yetenek, özel yetenek gibi çeşitli kavramların kullanıldığı görülmektedir (Bilgiç, 2017). 2011 yılında yayımlanan 652 sayılı KHK (Kanun Hükmünde Kararname) sonrasında özel yetenekli kavramının yer aldı̆̆ı, 2013 yılında yayımlanan strateji belgesi sonrasında da özel yetenekli kavramının kabul gördüğü ve kullanıldığı bilinmelidir.

1980'li yıllar sonrasında gerek millî eğitim şûralarında ve gerekse kalkınma planlarında özel yetenekli öğrencilerin eğitiminin önemine yer verilmesinin bugün yapılan çalışmalara zemin hazırladığı düşünülebilir (Sak vd., 2015). Deniz (2001), 2000'li yıllara kadar olan zamanda düzenlenen şûralarda çeşitli özür grupları yer alırken ve yetenek ön plana çıarılırken diğer taraftan özel yetenekli bireylerin eğitimine yönelik yapılan herhangi bir çalışmanın olmadığını ifade etmektedir. Ona göre bu şekilde bir ihtiyacı şûra gündemine almak bile akıllara gelmemiş olabilir.

2009 yılında özel yetenekli bireyler strateji ve uygulama planının hazırlanmasına ilişkin resmî gazetenin yayımlanması sonrasında yaklaşık dört yıl özel yetenekli bireylerin eğitimi ile ilgili tarafların görüşleri yapılan toplantı, çalıştay, sempozyum vb. etkinliklerde alındığı bilinmektedir (MEB, 2013). Farkındalığın artması, toplumun geniş bir kesiminin görüşünün alınması ve yapılacak çalışmalara yol göstermesi bakımından önem arz eden strateji ve uygulama planını gerçekleştirilen çalışmalar, kısmen gerçekleştirilen çalışmalar ve gerçekleştirilemeyen çalışmalar şeklinde kategorilendirerek değerlendirmeninde yararlı olacağı düşünülmektedir. 
Gerçekleştirilen çalışmalar. Özel yeteneklilerin eğitimine yönelik yerelde ve ülkemiz genelinde öğretmen eğitimlerinin her yıl yapıldığı görülmektedir. Diğer taraftan okullarda destek eğitim alan ve BİLSEM'e devam eden özel yeteneklilerin ailelerine ilişkinde aile eğitim programlarının hazırlandığı ve uygulandığı bilinmektedir (MEB, 2019).

Kısmen gerçekleştirilen çalışmalar. Tüm eğitim kademelerinde önerilen öğrenci kişisel dosyalarının hazırlanmasına ilişkin çalışmalara bakıldığında bunun yayımlanan 2023 eğitim vizyonu raporunda yer aldığı görülmektedir (MEB, 2018b). Yayımlanan raporda yalnız özel yetenekli öğrencileri değil tüm öğrencileri kapsamaktadır. Benzer şekilde yetenek atölyelerinin açılmasına yönelik çalışmalarında 2023 eğitim vizyonu belgesinde yer almaktadır. Yine özel yetenekli bireylerin bulunduğu ortamda kaynaştırma/Bütünleştirmesine yönelik çalışmaların devam ettiği ancak istendik düzeyde olmadığı gözlenmektedir. Diğer yandan hazırlanması gereken bireyselleştirilmiş eğitim programına ilişkin ise yeteri kadar yol alınamadığı söylenebilir (Bedur, Bilgiç ve Taşlıdere, 2015; Pemik ve Levent, 2019). Özel yetenekli bireylerin destek eğitim odalarında eğitim almalarına ilişkin de henüz yeni yeni çalışmaların olduğu ve istendik düzeyde olmadığı bilinmektedir (Kış, 2013; Akalın, 2014; Bedur vd., 2015; Pemik ve Levent, 2019).

Gerçekleştirilemeyen çalışmalar. Okul öncesi ve ilkokulda önerilen gelişim testlerinin yerine zekâ testlerinin uygulandığı görülmektedir (MEB, 2015b). Hizlandırma (erken okula başlatma, sınıf yükseltme) ile ilgili çalışmalara bakıldığında mesafe alınamadığı ve 2000'li yıllarda olduğu gibi sadece ilkokulda sınıf yükseltmenin olduğu bilinmektedir (MEB, 2014c). Oysa dünyadaki uygulamalara bakıldığında sınıf yükseltmenin her kademede olduğu bilinmektedir (Mönks ve Pflüger, 2005). Son olarak ise strateji ve uygulama planında yer alan eğitim bölgeleri yetenek gruplarının oluşturulmasına ilişkin ise herhangi çalışma yapılamadığı söylenebilir.

Bütüncül bir politika oluşturamama sorununa (Kılıç, 2015) rağmen dönem dönem özel yetenekli bireylerin eğitiminde toplumun beklentilerini karşılayacak kararların alındığı ancak uygulamada aynı başarının gösterilemediği görülmektedir. Asri'ye (2015) göre şûralarda ne karar alınırsa alınsın onu uygulayacak olan hükümet ve hükümet içindeki siyasiler ve bürokratlardır. Dolayısıyla özel yetenekli bireylerin eğitimi bundan sonra düzenlenecek şûralarda özel eğitim gereksinimi olan bireyler adı altında gündem maddesi olarak alınmalı ve bir bütünlük içerisinde değerlendirilmelidir.

Şûraların düzenlenmesi ve konuların belirlenmesi içinde bulunulan dönemin sorunlarının çözülmesine ilişkin olduğu söylenebilir (Ambarlı, 2010). Ancak şûralarda alınan kararların tavsiye niteliğinde olması ve yaptırım gücünün olmaması nedeni ile bazı kararların hiç uygulanamadığı veya bazı kararlardan kısa bir süre sonra vazgeçildiği söylenebilir.

Çalışmadan elde edilen sonuçlara dayanarak getirilen öneriler aşağıdadır:

- İlgili taraflarca kabul görecek kısa, orta ve uzun dönemli hedeflerin yer aldığı ikinci bir strateji belgesi veya doküman hazırlanmalı ve uygulanmalıdır.

- Özel yetenekli bireylerin eğitimine ilişkin AR-GE çalışmaları yapılmalı ve elde edilen sonuçlar doğrultusunda uygulamaya geçilmelidir.

- Düzenlenecek XX. millî eğitim şûrasında özel eğitim-özel yeteneklilerin eğitimi komisyonu 
kurulmalı ve alınan kararlar uygulanmalıdır.

\section{Kaynakça}

Akalın, S. (2014). Okul öncesi eğitim kurumlarında çalışan rehber öğretmenlerin kaynaştırma uygulamalarına ilişkin gereksinimleri. International Journal of Early Childhood Special Education (INT-JECSE), 6(1), 115-142.

Akkanat, H. (2004). Üstün veya özel yetenekliler. M. R. Şirin., A. Kulaksızoğlu ve A. E. Bilgili (Ed.), Seçilmiş makaleler kitabı içinde, (s. 167-193). İstanbul: Çocuk Vakfı Yayınları.

Ambarlı, A. (2010). Türkiye'de Cumhuriyet'ten günümüze sosyal bilgiler programları: Değişiklikler, düzenlemeler, güncellemeler (Yayımlanmamış yüksek lisans tezi). Selçuk Üniversitesi Eğitim Bilimleri Enstitüsü, Konya.

Ataman, A. (2012). Özel gereksinimli çocuk. A. Ataman (Ed.), Temel eğitim öğretmenleri için kaynaştırma uygulamaları ve özel eğitim içinde (s. 25-54). Ankara: Vize Yayıncılık.

Ataman, A. (2014). Giriş. A. Ataman (Ed.), Üstün zekâlllar ve üstün yetenekliler konusunda bilinmesi gerekenler içinde (s. 7-27). Ankara: Vize Yayıncılık.

Asri, S. (2015). Türkiye'de eğitim politikalarının aktörleri. A. Gümüş (Ed.), Türkiye'de eğitim politikaları içinde (s. 77-108). Ankara: İlem Kitaplığı-Nobel Akademik Yayıncılık.

Başbakanlık, (2017). Başbakanlık geçmiş hükümetler. https://www.basbakanlik.gov.tr/Forms/_Global/_Government/pg_CabinetHistory.aspx adresinden erişilmiştir.

Bedur, S., Bilgiç, N. ve Taşlıdere, E. (2015). Özel (üstün) yetenekli öğrencilere sunulan destek eğitim hizmetlerinin değerlendirilmesi. Hasan Ali Yücel Ĕ̆itim Fakültesi Dergisi, 12-1(23), 159-175.

Bilgiç, N. (2017). Üstün zekâlı ve yetenekli bireylerin eğitimi politikalarına yönelik nitel bir çalışma (Yayımlanmamış doktora tezi). Gazi Üniversitesi Eğitim Bilimleri Enstitüsü, Ankara, Türkiye.

Can, N. (1999). Onuncu millî eğitim şûrası kararları ışığında millî eğitim bakanlığı merkez örgütü hiyerarşik yapısının değerlendirilmesi. Sosyal Bilimler Enstitüsü Dergisi, 8, 181-194.

Çakır, C. (2017). Geçmişten günümüze Türk eğitim sistemindeki gelişmeler: Bir kamu politikası aktörü olarak millî eğitim şûraları özelinde bir değerlendirme. Sosyal ve Beşeri Bilimleri Dergisi, 9(2), 31-48.

Çoban, Ö. (2016). Millı̂ eğitim bakanlığı merkez teşkilatı yöneticilerinin örgütsel değişimi yönetme yeterlikleri ile stratejik liderlik davranışları arasındaki ilişkinin incelenmesi (Yayımlanmamış doktora tezi). Gazi Üniversitesi Eğitim Bilimleri Enstitüsü, Ankara.

Creswell, J. W. (1998). Qualitative inquiry and research design: Choosing among five traditions. Thousand Oaks, CA: Sage Publications.

Davaslıgil, Ü. (2004). Üstün zekâlı çocukların eğitimi. M. R. Şirin., A. Kulaksızoğlu. ve A., E., Bilgili (Ed.), Seçilmiş makaleler kitabı içinde (ss. 233-241). İstanbul: Çocuk Vakfı Yayınları.

Deniz, M. (2001). Millî eğitim şûralarının tarihçesi ve eğitim politikalarına etkisi (Yayımlanmamış yüksek lisans tezi). Süleyman Demirel Üniversitesi Sosyal Bilimler Enstitüsü, Isparta.

Dinç, S. (2008). Cumhuriyet dönemi eğitim tarihimizde I. millî eğitim şûrası (17-23 Temmuz 1939) ve uygulamaları.http://turkoloji.cu.edu.tr/ATATURK/arastirmalar/sait_dinc_I_milliegitim_surasi.pdf adresinden erişilmiştir.

Eriş, S. (2006). 1961-1987 yılları arasında gerçekleştirilen millî eğitim şûraları ve alınan kararların uygulamaları (Yayımlanmamış yüksek lisans tezi). Selçuk Üniversitesi Sosyal Bilimler Enstitüsü, Konya, Türkiye.

Gümüşgül, O. ve Göral, M. (2014). Millî eğitim şûraları kapsamında beden eğitimi dersi. Sportif Bakış: Spor ve Eğitim Bilimleri Dergisi, 1(1), 14-29.

Güven, S. (2016). 1933 yılı reformundan günümüze üniversiteler ve millî eğitim şûraları kararları. Eğitimde Kuram ve Uygulama, 12(4), 928-944. 
Güzel, A. (1973). Cumhuriyet döneminde üstün yetenekli çocukların yetiştirilmesine ilişkin yasal olanaklar. Ankara Üniversitesi Ĕ̆itim Fakültesi Yayınları, 36, 175-186.

Güzel, D. ve Şimşek, A. (2012). Millî eğitim şûralarında ders kitapları. Sakarya Üniversitesi Eğitim Fakültesi Dergisi, 23(23), 172-216.

Heller, K. A. (2004). Identification of gifted and talented students. Psychology Science, 46(3) 302-323.

Kılıç, V. C. (2015). Türkiye'de üstün ve özel yetenekli çocuklara yönelik bir eğitim politikası oluşturulamaması sorunu üzerine bir değerlendirme. 21. Yüzyılda Eğitim ve Toplum, 4(12), 145154.

Kış, H. (2013). Destek eğitim odalarındaki uygulamalara ilişkin rehber öğretmenler ve özel eğitim sinıf öğretmenlerinin görüşleri (Yayınlanmamış yüksek lisans tezi). Abant İzzet Baysal Üniversitesi Eğitim Bilimleri Enstitüsü, Bolu, Türkiye.

MEB (1933). Maarif vekâleti merkez teşkilâtı ve vazifeleri hakkında kanun. https://www.resmigazete.gov.tr/arsiv/2434.pdf adresinden erişilmiştir.

MEB (1953). Millî eğitim bakanlığı V. millî eğitim şûrası. http://ttkb.meb.gov.tr/meb_iys_dosyalar/2017_09/29164807_5_sura.pdf adresinden erişilmiştir.

MEB (1962). Millî eğitim bakanlı̆̆̊ VII. millî eğitim şûrası. http://ttkb.meb.gov.tr/meb_iys_dosyalar/2017_09/29164924_7_sura.pdf adresinden erişilmiştir.

MEB (1974). Millî eğitim bakanlığı IX. millî eğitim şûrası. http://ttkb.meb.gov.tr/meb_iys_dosyalar/2017_09/29165045_9_sura.pdf adresinden erişilmiştir.

MEB (1982). Millî eğitim bakanlığı XI. millî eğitim şû̂rası. http://ttkb.meb.gov.tr/meb_iys_dosyalar/2017_09/29165200_11_sura.pdf adresinden erişilmiştir.

MEB (1988). Millı̂ eğitim bakanlı̆̆ı XII. millî eğitim şûrası. http://ttkb.meb.gov.tr/meb_iys_dosyalar/2017_09/29165252_12_sura.pdf adresinden erişilmiştir.

MEB (2006a). Millî eğitim bakanlı̆̆ı XVII. millî eğitim şûrası. http://ttkb.meb.gov.tr/meb_iys_dosyalar/2017_09/29165619_17_sura.pdf adresinden erişilmiştir.

MEB (2006b). Millî eğitim bakanlı̆̆ı özel eğitim hizmetleri yönetmeliği. https://www.resmigazete.gov.tr/eskiler/2006/05/20060531-2.htm adresinden erişilmiştir.

MEB (2010). Millî eğitim bakanlığı XVIII. millî eğitim şûrası. http://ttkb.meb.gov.tr/meb_iys_dosyalar/2017_09/29170222_18_sura.pdf adresinden erişilmiştir.

MEB (2013). Üstün (Özel) yetenekli bireyler strateji ve uygulama planı 2013-2017. Anakara: Millî Eğitim Bakanlı̆̆

MEB (2014a). Millî eğitim bakanlı̆̆ı millî eğitim şûrası yönetmeliği. https://www.resmigazete.gov.tr/eskiler/2014/07/20140708-4.htm adresinden erişilmiştir.

MEB (2014b). Millî eğitim bakanlığı XIX. millî eğitim şûrası. http://ttkb.meb.gov.tr/meb_iys_dosyalar/2019_12/10095332_19_sura.pdf adresinden erişilmiştir.

MEB (2014c). Millî eğitim bakanlı̆̆l okul öncesi eğitim ve ilköğretim kurumları yönetmeliği. https://www.resmigazete.gov.tr/eskiler/2014/07/20140726-4.htm adresinden erişilmiştir.

MEB (2015a). Millî eğitim bakanlığı bilim ve sanat merkezleri yönergesi. file:///C:/Users/FBI/Downloads/2698_Kasim\%202015.pdf adresinden erişilmiştir.

MEB (2015b). Millı̂ eğitim bakanlığı bilim ve sanat merkezleri öğrenci tanılama kılavuzu. https://orgm.meb.gov.tr/meb_iys_dosyalar/2015_11/19105341_rencitanlamaklavuzu.pdf adresinden erişilmiştir.

MEB (2016). Millı̂ eğitim bakanlı̆̆ı bilim ve sanat merkezleri yönergesi. file:///C:/Users/FBI/Downloads/2710_Kasim_2016.pdf adresinden erişilmiştir.

MEB (2017a). Millî eğitim bakanlığı talim ve terbiye kurulu başkanlığı kurul ve şûra işleri başkanlığı. https://www.resmigazete.gov.tr/eskiler/2011/09/20110914-1.htm adresinden erişilmiştir.

MEB (2017b). Millî eğitim bakanlı̆̆ı müfredatta yenileme ve değişiklik çalışmalarımı üzerinehttps://ttkb.meb.gov.tr/meb_iys_dosyalar/2017_07/18160003_basin_aciklamasi-program.pdf adresinden erişilmiştir. 
MEB (2017c). Millî eğitim bakanlı̆̆ı kurum açma, kapatma ve ad verme yönetmeliği. https://www.resmigazete.gov.tr/eskiler/2017/06/20170624-5.htm adresinden erişilmiştir.

MEB (2017d). Millî eğitim bakanlığı strateji geliştirme başkanlı̆̆ı millî eğitim istatistikleri. https://sgb.meb.gov.tr/meb_iys_dosyalar/2017_03/31152628_meb_istatistikleri_orgun_egitim_2016_2017_1.pdf adresinden erişilmiştir.

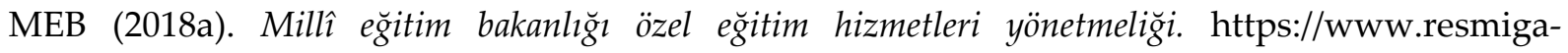
zete.gov.tr/eskiler/2018/07/20180707-8.htm adresinden erişilmiştir.

MEB, (2018b). Mutlu çocuklar güçlü Türkiye - 2023 eğitim vizyonu. Ankara: Millî Eğitim Bakanlığı.

MEB, (2019). Aile ve öğretmen eğitimleri. https://orgm.meb.gov.tr/ adresinden erişilmiştir.

Memduhoğlu, H. B. ve Taymur, A. (2014). Türkiye' de eğitim denetimi alt sisteminin yeniden yapılandırılmasına ilişkin model önerisi. Pegem Ĕ̆itim ve Öğretim Dergisi, 4(2), 25-44.

Merriam, S. (1998). Qualitative research and case study applications in education. San Francisco: JosseyBass.

Mönks, F. J., \& Pflüger, R. (2005). Gifted education in 21 European countries: Inventoryand perspective. Radboud University Nijmegen.

ÖSYM (2017). Ölçme, seçme ve yerleştirme merkezi baskanligi tarihsel gelişme. Erişim adresi: http://www.osym.gov.tr/TR,8530/tarihsel gelisme.html

Pemik, K. ve Levent, F. (2019). Üstün yetenekli öğrencilere destek odasında verilen eğitime ilişkin okul yöneticilerinin ve öğretmenlerin görüşleri. Ankara Üniversitesi Eğitim Bilimleri Fakültesi Özel Ĕ̆itim Dergisi, 20, 1-26.

Sak, U. (2010). Üstün zekâlılar özellikleri tanılanmaları ve eğitimleri. Ankara: Maya Yayıncılık.

Sak, U. (2011). Prevalence of misconceptions, dogmas and popular views about giftedness and intelligence: A case from Turkey. High Ability Studies, 22(2), 179-197.

Sak, U., Ayas, B., M., Bal-Sezerel, B., Öpengin, E., Özdemir, N., N. ve Demirel-Gürbüz, Ş. (2015). Türkiye' de üstün yeteneklilerin eğitiminin eleştirel bir değerlendirmesi. Türk Üstün Zekâ ve Eğitim Dergisi, 5(2), 110-132.

Sak, U., Bal-Sezerel, B., Ayas, B., Tokmak, F., Özdemir, N. N., Demirel-Gürbüz, Ş. ve Öpengin, E. (2016). Anadolu Sak zekâ ölçeği (ASİS) uygulayıcı kitabı. Eskişehir: Anadolu Üniversitesi ÜYEP Merkezi.

TBMM (1967). Tutanak. https://www.tbmm.gov.tr/tutanaklar/TUTANAK/MM_/d02/c016/b093/mm_020160930452 adresinden erişilmiştir.

TBMM (2012). Üstün yetenekli çocukların keşfi, eğitimleriyle ilgili sorunların tespiti ve ülkemizin gelişimine katkı sağlayacak etkin istihdamlarının sağlanması amacıyla kurulan meclis araştırması komisyonu raporu. https://acikerisim.tbmm.gov.tr/xmlui/bitstream/handle/11543/129/ss427.pdf?sequence=1\&isAllowed=y adresinden erişilmiştir.

Tofur, S., Aypay, A. ve Yücel, C. (2016). 1980-2014 Türk millî eğitim şûra kararları ile tebliğler dergisi fihristlerinin karşılaştırmalı değerlendirilmesi. Ĕ̆itim ve Bilim, 41(186), 253-274.

Tunçdemir, İ. (2008). Çoksesli müzikte harika çocuk kanunun Türk müzik kültürüne etkisi. İdil Biret-Suna Kan örneği. Millı̀ Ĕ̆itim Dergisi, 36(177), 8-26.

Yıldırım, A. ve Şimşek, H. (2013). Sosyal bilimlerde nitel araştırma yöntemleri. Ankara: Seçkin Yayıncrlik.

Uzun, Y. ve Üstten, U. A. (2010). Millî eğitim şûraları ve Türkçe'nin ana dil olarak öğretimi. Ekev Akademi Dergisi, 14(44), 137-144. 